\title{
Malignant Lung and Pleural Neoplasm
}

National Cancer Institute

\section{Source}

National Cancer Institute. Malignant Lung and Pleural Neoplasm. NCI Thesaurus. Code C45625.

A primary or metastatic malignant neoplasm that affects the lung and pleura. 